\title{
Uji daya hambat ekstrak daun mengkudu (Morinda citrifolia L.) terhadap pertumbuhan Candida albicans secara in vitro
}

\author{
${ }^{1}$ Olivia C. Simatupang \\ ${ }^{2}$ Jemmy Abidjulu \\ ${ }^{3}$ Krista V. Siagian
}

\author{
${ }^{1}$ Kandidat Skripsi Program Studi Pendidikan Dokter Gigi Fakultas Kedokteran \\ ${ }^{2}$ Bagian Kimia Fakultas MIPA \\ ${ }^{3}$ Program Studi Pendidikan Dokter Gigi Fakultas Kedokteran \\ Universitas Sam Ratulangi Manado \\ Email: cindysimatupang12@yahoo.com
}

\begin{abstract}
Candida albicans is a normal flora of the mouth, respiratory tract, gastrointestinal tract and the female genital but it becomes pathogen if there is a predisposing factor. Approximately $85-95 \%$ of oral candida infections are caused by $C$. albicans that is usually attached to the labial mucosa, buccal mucosa, the dorsal parts of the tongue and palate. Noni (Morinda citrifolia L.) is already known as a medical plant; one of it parts that has a medicinal effect is the leaf that contains anthraquinon as an antifungal. This study was aimed to determine the effect of noni leaf extract to the growth of $C$. albicans. This was a true experimental in vitro study with the post test only group design. The Kirby-Bauer method with filter paper was used to evaluate the sensitivity of $C$. albicans to mengkudu leaf extract. Leaves samples were extracted by using maceration process with ethanol 96\%. C. albicans obtained from the pure stock of Laboratory of Microbiology Pharmacy Faculty of Math and Science, University of Sam Ratulangi. The results showed that the inhibition zone diameter of noni leaf extract on the growth of C. albicans was 16 $\mathrm{mm}$ (strong inhibition category). Conclusion: Noni leaf extract (Morinda citrifolia L.) had an inhibitory effect on Candida albicans.
\end{abstract}

Keywords: Mengkudu leaf (Morinda citrifolia L.), Candida albicans, inhibition zone

\begin{abstract}
Abstrak: Candida albicans merupakan anggota flora normal rongga mulut, saluran pernafasan, saluran pencernaan, dan genital wanita namun dapat menjadi patogen jika terdapat faktor predisposisi. Sekitar $85-95 \%$ infeksi kandidiasis oral disebabkan oleh $C$ albicans yang biasanya melekat pada mukosa labial, mukosa bukal, dorsum lidah dan palatum. Tanaman mengkudu (Morinda citrifolia L.) telah dikenal sebagai tumbuhan obat. Salah satu bagian tanaman mengkudu yang memiliki efek obat ialah daunnya karena adanya kandungan antrakuinon yang bersifat antijamur. Penelitian ini bertujuan untuk mengetahui efek ekstrak daun mengkudu terhadap pertumbuhan $C$. albicans. Jenis penelitian ini ialah eksperimental laboratorik secara in vitro dengan post test only group design. Pengujian menggunakan metode Kirby-Bauer berbahan kertas saring. Sampel daun diekstraksi dengan proses maserasi menggunakan etanol 96\%. Jamur C. albicans diambil dari stok biakan jamur murni Laboratorium Farmasi FMIPA Universitas Sam Ratulangi Manado. Hasil penelitian mendapatkan diameter zona hambat ekstrak daun mengkudu terhadap pertumbuhan $C$. albicans $16 \mathrm{~mm}$ yang tergolong kriteria zona hambat kuat. Simpulan: Ekstrak daun mengkudu (Morinda citrifolia L.) mempunyai daya hambat terhadap jamur Candida albicans.
\end{abstract}

Kata kunci: daun mengkudu, Candida albicans, zona hambat

Candida albicans merupakan anggota flora normal rongga mulut yang biasanya tidak menyebabkan kerusakan dan hidup bersimbiosis dengan manusia. Organisme ini dapat menimbulkan infeksi oportunistik jika terdapat faktor-faktor predisposisi yang 
mendukung seperti kondisi imunosupresi, penggunaan antibiotik spektrum luas, pemakaian gigi tiruan, merokok, dan xerostomia. Sekitar $85-95 \%$ infeksi kandidiasis oral disebabkan oleh jamur Candida albicans yang biasanya melekat pada mukosa labial, mukosa bukal, dorsum lidah, dan daerah palatum. Kasus kandidiasis oral dapat disebabkan oleh beberapa campuran spesies Candida, tetapi penyebab paling utamanya yaitu Candida albicans. ${ }^{1-4}$

Mengkudu merupakan salah satu tanaman yang memiliki efek farmakologik. ${ }^{5,6}$ Kulit, akar, daun, dan buah mengkudu mengandung senyawa yang dipercaya memiliki efek farmakologik bagi kesehatan tubuh seperti protein, zat kapur, zat besi, karoten, askorbin, senyawa moridin, moridon, aligerin-d-methyleter, soranyideal, xeronin, proxeronin, vitamin $\mathrm{A}$, vitamin $\mathrm{C}$, anti oksidan, mineral (kalium, natrium, kalsium, zat besi), protein, karbohidrat, kalori, lemak, niamin, thiamin dan riboflavin, alkaloida, saponin, flavonoida, antrakinon, polifenol, metal asetil ester. $^{7-9}$

Mengkudu (Morinda citrifolia L.) merupakan tanaman yang banyak tumbuh di Indonesia dan menjadi salah satu tanaman obat yang cukup potensial untuk dikembangkan. ${ }^{8,9}$ Menurut data Direktorat Jenderal Tanaman Pangan dan Hortikultura, pada tahun 2004 luas panen tanaman mengkudu di Jawa Barat mencapai 2,581 ha dengan produksi $3.509,087$ ton atau produktivitas tanaman $4,83 \mathrm{~kg} / \mathrm{m} 2{ }^{5}$

Pemanfaatan mengkudu sebagai obat dan sayuran dipergunakan untuk mengobati berbagai penyakit seperti tumor, luka, penyakit kulit, gangguan pernafasan (asma), demam dan penyakit usia lanjut. Masyarakat di Amerika Tengah juga menyebut mengkudu sebagai pain killer tree karena diketahui bahwa sari buah mengkudu berfungsi sebagai adaptogen yang dapat menyeimbangkan fungsi sel-sel dan juga menormalkan fungsi otak tempat pengendalian rasa sakit. ${ }^{8-10}$

Daun mengkudu (Morinda citrifolia
L.) memiliki kandungan antrakuinon yang terbukti mempunyai efek farmakologik sebagai lisosim terhadap sel bakteri dan jamur. Aloin, emodin, barbaloin, saponin, tannin dan sterol merupakan campuran kandungan dalam antrakuinon yang bersinergi dan berkontribusi menjadi suatu khasiat penyembuh yang bersifat analgesik, antiseptik, antiinflamasi, antibakteri dan antijamur. $^{11-13}$

Penelitian ini bertujuan untuk mengetahui efek ekstrak daun menkudu terhadap pertumbuhan jamur Candida albicans dan mengetahui besarnya zona hambat yang dihasilkan ekstrak daun mengkudu pada pertumbuhan jamur Candida albicans.

\section{BAHAN DAN METODE PENELITIAN}

Jenis penelitian ini ialah eksperimental laboratorik dengan post-test only control group design. Penelitian ini dilaksanakan di Laboratorium Farmasi Fakultas MIPA Universitas Sam Ratulangi pada bulan April s/d Agustus 2016.

Daun mengkudu (Morinda citrifolia L.) yang diperoleh dari pekarangan warga Paniki Satu sebanyak 1500 gr yang dibuat dengan proses maserasi. Daun yang telah dikeringkan tanpa sinar matahari kemudian diblender hingga menjadi serbuk. Serbuk daun mengkudu kemudian ditimbang seberat 100 gr dan direndam dalam etanol 96\% sebanyak $1000 \mathrm{ml}$, sambil diaduk setiap harinya untuk melepaskan zat aktif dalam daun mengkudu.

Larutan kemudian disaring dengan corong bucher dan kertas saring kemudian diuapkan dari sisa pelarutnya dengan evaporator pada suhu $40^{\circ} \mathrm{C}$ menghasilkan 20 gr ekstrak kering. Setelah itu, ekstrak murni yang didapat dimasukan ke dalam oven dengan suhu $40^{\circ} \mathrm{C}$ lalu dituang ke dalam botol steril kaca tertutup dan disimpan di lemari pendingin.

Potato Dextrose Agar (PDA) ditimbang seberat 21 gr menggunakan $500 \mathrm{ml}$ akuades sebagai pelarut kemudian dimasukkan ke dalam gelas kimia. Gelas kimia kemudian ditutup dengan aluminium foil dan disterilkan dalam autoklaf dengan 
temperatur $121^{\circ} \mathrm{C}$ selama $15-20$ menit. Larutan PDA dimasukkan dalam cawan petri sebanyak masing-masing $20 \mathrm{ml}$ di setiap cawan petri lalu dibiarkan mengeras kurang lebih 30 menit.

Pembuatan suspensi jamur dilakukan dengan mengambil jamur Candida albicans dan dimasukkan ke dalam tabung reaksi yang berisi larutan $\mathrm{NaCl} 0,9 \%$ sebanyak 3 $\mathrm{ml}$, kemudian dicampur hingga homongen ditandai dengan cairan berubah menjadi keruh sesuai standar kekeruhan McFarland.

Kertas saring bersih yang belum terkontaminasi apapun disediakan sebanyak 15 buah. Masing-masing 5 buah direndam dalam cawan petri yang berisi ekstrak daun mengkudu (Morinda citrifolia L.), akuades, dan larutan ketokonazol kurang lebih selama 30 menit.

Jamur ditanam pada masing-masing cawan petri berisi Potato Dextrose Agar (PDA) dengan cara suspensi jamur diambil menggunakan micropipette sebanyak 400 $\mu \mathrm{l}$ untuk masing-masing cawan Petri. Jamur yang telah diletakkan dalam media agar kemudian diratakan menggunakan spreader. Setiap pekerjaan laboratorium dilakukan di dekat api Bunsen guna menjaga sterilitasnya. Selanjutnya, cawan petri dimasukkan ke dalam inkubator selama 24 jam dengan suhu $37^{\circ} \mathrm{C}$. Hasil perlakuan diamati secara visual ada tidaknya pertumbuhan koloni Candida albicans.

Davis dan Stout membuat kategori untuk aktivitas penghambatan berdasarkan diameter zona hambat sebagai berikut: ${ }^{14}$

1. Zona hambat $20 \mathrm{~mm}$ atau lebih dikategorikan sangat kuat.

2. Zona hambat $11-20 \mathrm{~mm}$ dikategorikan kuat.

3. Zona hambat $5-10 \mathrm{~mm}$ dikategorikan sedang.

4. Zona hambat $5 \mathrm{~m}$ atau kurang dikategorikan lemah.

Zona hambat yang terbentuk di sekitar kertas saring diukur diameter vertikal dan diameter horizontal dalam satuan millimeter (mm). Rumus pengukuran zona hambat sebagai berikut:
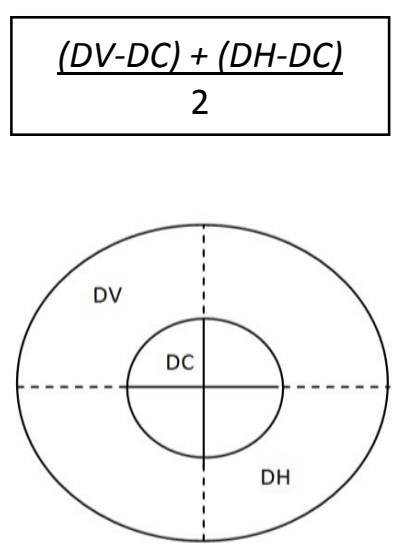

Gambar 1. Pengukuran diameter zona hambat

Keterangan :

\begin{tabular}{ll}
\hline & $:$ Zona hambat \\
\hline DV & : Diameter vertikal \\
DH & : Diameter Horizontal \\
DC & : Diameter Cakram
\end{tabular}

\section{HASIL PENELITIAN}

Penelitian ini menunjukkan terdapat daya hambat ekstrak daun mengkudu (Morinda citrifolia L.) terhadap pertumbuhan jamur Candida albicans.

Hal ini dinyatakan dengan terlihatnya zona bening pada sekitar kertas saring yang berisikan ekstrak daun mengkudu.

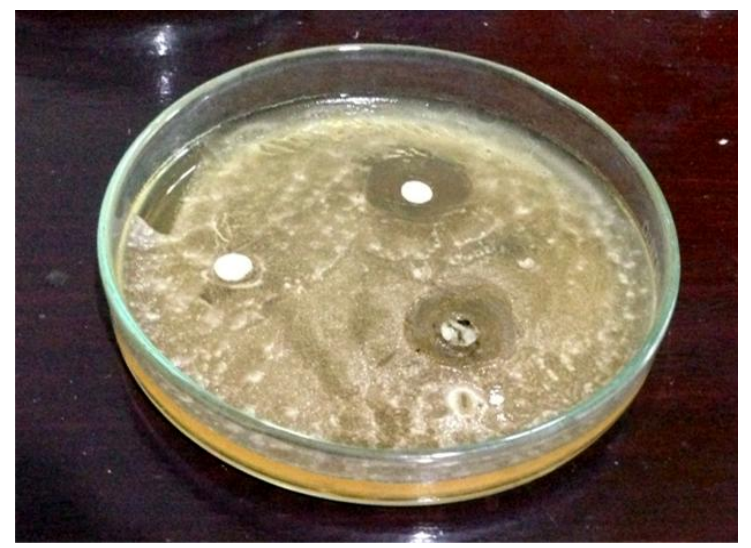

Gambar 2. Zona hambat yang terbentuk pada media Potato Dextrose Agar

Dari lima cawan petri terlihat ketokonazol dan ekstrak daun mengkudu (Morinda citrifolia L.) sama-sama memiliki daya hambat terhadap pertumbuhan jamur Candida albicans. 
Tabel 1. Diameter zona hambat ekstrak daun mengkudu (Morinda citrifolia L), obat ketokonazol (kontrol+), akuades (kontrol -)

\begin{tabular}{cccc}
\hline \multirow{2}{*}{$\begin{array}{c}\text { Cawan } \\
\text { Petri }\end{array}$} & $\begin{array}{c}\text { Ekstrak daun } \\
\text { mengkudu } \\
\text { (M. citrifolia } \text { L.) }\end{array}$ & $\begin{array}{c}\text { Ketokonazol } \\
\text { (kontrol +) }\end{array}$ & $\begin{array}{c}\text { Etanol 96\% } \\
\text { (kontrol -) }\end{array}$ \\
\hline 1 & 15,0 & 18,5 & 0,0 \\
2 & 17,5 & 20,0 & 0,0 \\
3 & 16,0 & 20,5 & 0,0 \\
4 & 16,0 & 20,0 & 0,0 \\
5 & 15,5 & 18,5 & 0,0 \\
Total & 80,0 & 97,5 & 0,0 \\
Rerata & 16,0 & 19,5 & 0,0 \\
Kategori & Kuat & Kuat & - \\
\hline
\end{tabular}

Diameter daya hambat yang terlihat dihitung reratanya dan didapatkan rerata diameter zona hambat ekstrak daun cengkeh sebesar $16,0 \mathrm{~mm}$ dengan aktifitas penghambatan kuat dan diameter zona hambat ketokonazol sebagai kontrol positif sebesar 19,5 $\mathrm{mm}$ dengan aktifitas penghambatan kuat terhadap jamur $C$. albicans, sedangkan kontrol negatif dalam hal ini larutan etanol 96\% tidak menunjukan adanya zona hambat.

\section{BAHASAN}

Penelitian ini merupakan uji eksperimental guna mengetahui efek anti jamur dari ekstrak daun mengkudu (Morinda citrifolia L.) dalam menghambat pertumbuhan jamur $C$. albicans. Hasil penelitian menunjukkan adanya daya hambat dari ekstrak daun mengkudu terhadap pertumbuhan jamur $C$. albicans setelah proses inkubasi selama 24 jam dalam inkubator dengan suhu $37^{\circ} \mathrm{C}$. Hal tersebut dinyatakan dengan terlihatnya zona hambat jamur di sekitar kertas saring ekstrak daun mengkudu.

Penelitian ini menggunakan kertas saring sebagai media perlekatan ekstrak. Kertas saring memiliki kelemahan yaitu tidak dapat mengukur jumlah ekstrak yang diserap untuk diujikan pada jamur. Berdasarkan hal tersebut peneliti mengambil langkah untuk meminimalisir bias dengan cara merendam lima kertas saring yang digunakan ke dalam ekstrak daun mengkudu secara bersamaan selama tiga puluh menit kemudian diangkat secara bersamaan.

Pengamatan dilakukan pada lima cawan Petri dengan kertas saring yang diberi ekstrak daun mengkudu dan semua cawan Petri tersebut menunjukkan adanya zona hambat yang cukup besar di sekeliling kertas saring tersebut. Semua cawan Petri menunjukkan kategori aktivitas penghambatan yang kuat namun pada cawan Petri I dan $\mathrm{V}$ zona hambat yang terbentuk sedikit lebih kecil. Peneliti berasumsi bahwa pada cawan Petri I dan V jumlah jamur yang dibiakkan lebih banyak atau pada proses perataan dengan spreader tidak meratakan dengan baik.

Rerata diameter zona hambat ekstrak daun mengkudu sedikit lebih kecil dibandingkan dengan zona hambat antijamur ketokonazol meskipun tetap tergolong dalam kategori kuat. Hal ini mungkin disebabkan oleh tidak dilakukannya uji fitokimia terlebih dahulu terhadap daun mengkudu yang akan dijadikan bahan penelitian, sehingga tidak diketahui berapa kadar antrakuinon di dalam esktrak daun mengkudu yang digunakan dalam penelitian ini.

Penelitian ini menunjukan bahwa ekstrak daun mengkudu (Morinda citrifolia L.) memiliki efek antifungi untuk menghambat pertumbuhan jamur Candida albicans, namun kemampuan ini kurang kuat bila dibandingkan dengan antijamur 
ketokonazol yang aktif sebagai obat antijamur baik sistemik maupun nonsistemik. ${ }^{14-16}$

Hal ini mungkin dikarenakan konsentrasi kepekatan ekstrak daun mengkudu (Morinda citrifolia L.) belum diketahui minimal inhibitor concentration ekstrak terhadap jamur Candida albicans, sehingga besar zona hambat yang terbentuk belum sebanding dengan zona hambat yang terbentuk pada ketokonazol sebagai kontrol positif.

\section{SIMPULAN}

Berdasarkan hasil penelitian maka dapat disimpulkan bahwa ekstrak daun mengkudu (Morinda citrifolia L.) memiliki kemampuan menghambat pertumbuhan jamur Candida albicans dan diameter zona hambat yang terbentuk sebesar $16 \mathrm{~mm}$ tergolong dalam kriteria zona hambat yang kuat.

\section{SARAN}

Perlu dilakukan penelitian lebih lanjut mengenai efektivitas ekstrak daun mengkudu (Morinda citrifolia L.) terhadap pertumbuhan jamur Candida albicans pada berbagai konsentrasi kepekaan ekstrak untuk dapat mengetahui minimal inhibitor concentration terhadap daya hambat jamur Candida albicans. Penelitian selanjutnya, diharapkan daun mengkudu (Morinda citrifolia L.) dapat dibuat dalam formulasi yang tepat untuk dibuat menjadi sediaan obat antijamur yang dapat digunakan dalam penanggulangan infeksi kandida dalam bidang kedokteran gigi.

\section{DAFTAR PUSTAKA}

1. Burket LW, Greenberg MS, Glick M, Ship JA. Burket's Oral Medicine: Infectious diseases, oral candidiasis (11th ed). India: BC Decker Inc, 2008; p 79-84. [citeD 2016 feb 18] Available from: http://www.books.google.co.id

2. Maharani S, Oedijani-Santoso. Pengaruh pemberian larutan ekstrak Siwak (Salvadora persica) pada berbagai konsentrasi terhadap pertumbuhan
Candida albicans. Jurnal PDGI. 2012;61:61-4.

3. Bruch JM, Treister NS. Clinical Oral Medicine and Pathology. New York: Springer Science \& Business Media, 2009; p. 92. [cited 2016 Feb 18] Available from: http://www.books.google.co.id

4. Komariah, Sjam R. Kolonisasi Candida albicans dalam rongga mulut. Majalah Kedokteran Fakultas Kedokteran Universitas Kristen Indonesia. 2013;28(1):39-47.

5. Barkatullah, Ibrar M, Muhammad N, Tahir L. Antimicrobial evaluation, determination of total phenolic and flavoniod contents in Zanthoxylum armatum DC. J Med Plant Res. 2012; 6(11):2105-10.

6. Sunarni T, Prastiwi R, Mardiyono, Rinanto Y, Jannah NH, Wardani WW. The combined effect of an extract of Morinda citrifolia L. fruits and Carica papaya L. leaves on serum transaminase and bilirubin in antituberculosis-induced rats. International Conference: Research and Application on Traditional Complementary and Alternative Medicine in Health Care (TCAM), Surakarta, 2012; p 174-80.

7. Kameswari MS, Besung INK, Mahatmi H. Perasan daun mengkudu (Morinda citrifolia L.) menghambat pertumbuhan bakteri Escherichia coli secara in vitro. Indonesia Medicus Veterinus. 2013;2(3):322-30.

8. Krishnaiah D, Nithyanandam R, Sarbatly R. Phytochemical constituents and activities of Morinda citrifolia L. Universiti Malaysia Sabah, Malaysia. 2007;6:127-50.

9. Bestari J, Parakkasi A, Akil S. Pengaruh pemberian tepung daun mengkudu (Morinda citrifolia Linn) yang direndam air panas terhadap penampilan ayam broiler. Bogor: Seminar Nasional Teknologi Peternakan dan Veteriner, 2005; p. 703-15.

10. Sreeranjini S, Siril EA. Evaluation of antigenotoxity of the leaf extract of Morinda Citrifolia Linn. Plant Soil Environ. 2011; 6:222-7.

11. Setyawaty R, Ismunandar A, Nurul QA. 
Identifikasi senyawa antrakuinon pada daun mengkudu (Morinda citrifolia L) menggunakan kromatografi lapis tipis. Prosiding Seminar Nasional Hasil-hasil Penelitian dan Pengabdian LPPM UMP. Purwokerto, 2014; p. 384-7.

12. Etika SB, Suryelita. Isolasi steroid dari daun mengkudu (Morinda citrifolia L.). EKSAKTA. 2014;1:60-5.

13. Nala A. Manfaat Apotik Hidup untuk Perawatan Kesehatan dan Kecantikan. Temanggung: Yayasan Bina Karya Temanggung, Jawa Tengah, 2003; p. 46.

14. Bonev B, Hooper J, Parisot J. Principle of assessing bacterial susceptibility to antibiotics using the agar diffusion method. J Antimicrobial Chemother. 2008;61:1295-1301.

15. Marsh PD, Martin MV. Oral Microbiology (5th ed). Oxford: Wright, 2009; p 153-162 [cited 2016 Jul 20]. Available from: http://www.books.google.co.id

16. Harvey RA, Champe PC. Lippincott's Ilustrated Reviews: Pharmacology (5th ed) Lippiconcott William \& Wilkins, A Wolters Kluwer Company. 2012: p 432-5. [cited 2016 Aug 20]. Available from: http://www.google.books.co.id 